\title{
Pharmacotherapeutic Consideration of Gastro Esophageal Reflux Disease among Geriatric Type 2 Diabetic Patients
}

\author{
Mahin Gulzar Ahmed ${ }^{1}$, Syed Wasif Gillani ${ }^{2, *}$, Issam Haddad ${ }^{1}$, Khawla Mohamad Karim Ahmad ${ }^{1}$, Rukkaya Musa \\ Abdullahi ${ }^{1}$, Fatima Danlami Bello ${ }^{1}$, Nastaran Mohamadi ${ }^{1}$ \\ ${ }^{1}$ College of Pharmacy, Gulf Medical University, Ajman, UAE. \\ ${ }^{2}$ Department of Pharmacy Practice, College of Pharmacy, Gulf Medical University, Ajman, UAE.
}

Received: 11 October 2019

Accepted: 23 December 2019

*Correspondence to:

Dr. Syed Wasif Gillani, GCP Associate Professor, Department of Pharmacy Practice, College of Pharmacy, Gulf Medical University, AL JURF - 1 Rashid Al-Khadar St. Ajman, UAE.

Email:wasifgillani@gmail.com Copyright: (C) the author(s),publisher and licensee Indian Academy of Pharmacists. This is an open-access article distributed under the terms of the Creative Commons Attribution Non-Commercial License, which permits unrestricted non-commercial use, distribution, and reproduction in any medium, provided the original work is properly cited.

\begin{abstract}
Background: Gastro-esophageal Reflux disorder is return of the stomach's contents back up into the esophagus. Whereas diabetes is a metabolic disorder in which there is either no production of insulin or there is resistance to insulin being produced by body. Objectives: The aim of the systematic review is to study the pharmacotherapeutic consideration of GERD among elderly type 2 diabetes patients. Methods: This study analyzed 15 articles identified and selected according to the study criteria. PRISMA guidelines were used for identification and screening of literature. Data search covered several primary databases, including PubMed/MedLine, Wiley library, Scopus, Clinical Trial Registry, etc. Result and Findings: The data shows obese patients with $\mathrm{BMI}>30 \mathrm{~kg} / \mathrm{m} 2$ with type 2 diabetes have higher chances of GERD. The findings also suggested increase in socioeconomic status shows increase incidence of type 2 diabetes mellitus with time and it also plays vital role to lifestyle modifications such as physical exercise e and dietary habits. The prevalence values of GERD by skipping breakfast, snacking during bedtime, late night eating and eating fast were $32.0 \%, 13.7 \%, 27.1 \%, 28.8 \%$ and $44.4 \%$, respectively. Late night eating was independently positively associated with GERD in patients with type 2 diabetes; the adjusted odds ratio was 1.46 (95\% Cl 1.03 to 2.05). No relationships were found between not eating breakfast, snacking at bedtime or eating fast and GERD. Conclusion: The review findings suggested that patients with type 2 diabetes are at double risk of GERD as the metabolic disorder are making it worst. GERD can be avoided by minimizing the risk of type 2 diabetes either by controlling obesity by bariatric surgery or by exercise and more active lifestyle. There are some important considerations to decrease the incidence of GERD by evaluation and treatment in the older patients.
\end{abstract}

Key words: GERD, Geriatric, Diabetes Mellitus, Diet, Gastroenterology.

\section{INTRODUCTION}

Gastroesophageal Reflux disorder is the return of stomach's contents back up into the esophagus. Whereas diabetes is a metabolic disorder in which there is either no production of insulin or there is resistance to insulin being produced by body. GERD symptoms can encounter up to $75 \%$ in patients with diabetic. ${ }^{[1]}$ And any symptoms of gastrointestinal in diabetics indicate dysfunction of movement and the basis of neuropathy of these imbalances. ${ }^{[1,2]}$ Also people with GERD have symptoms like vomiting, nausea and they keep using Glp1-RA (Glucagon-like peptide-1 receptor agonists) and that lead to ulcer, so it is better to change to DDP4(Inhibitors of dipeptidyl peptidase 4). ${ }^{[2]}$ The comprehension between type 1 and type 2 in gastrointestinal disease is Type $2 \mathrm{DM}$ patients had slower gastric emptying, more hospitalizations, more gastric stimulator implantations, higher hemoglobin $\mathrm{A} 1 \mathrm{c}\left(\mathrm{HbA}_{1 \mathrm{c}}\right)$ and more anxiety vs T2DM patients. ${ }^{[1,2]}$ And certain studies show that complications of gastroesophageal reflux disease (GERD) happen more frequently in patients with diabetes mellitus (DM) than in non-diabetic patients. ${ }^{[1,3,4]}$ The prevalence of gastro esophageal reflux disease (GERD) in geriatric type 2 diabetic patient increase by $10 \%$ to $20 \%{ }^{[2]}$ Diabetes is a rising pandemic of new societies driven by obesity, aging population and improved survival in those affected. ${ }^{[5,6]}$ Due to limited literature available on GERD and Diabetes, this study is aimed to provide current therapeutic considerations for the treatment of GERD among Geriatric type 2 diabetic patient. ${ }^{[1,2,5]}$ It is also stated that type 2 diabetes increases the risk of GERD and Medications for diabetes can also cause irritation in stomach especially in elderly patients. ${ }^{[6,7]}$ Therefore, the study aimed to study the pharmacotherapeutic consideration of GERD among elderly type 2 diabetes patients.

\section{MATERIALS AND METHODS}

Search Subject

The literature was searched on the basis of Treatment of GERD, GERD related complications in geriatric, type 2 diabetes in geriatric and their pharmacotherapeutic values in geriatric patients, the risk of type 2 diabetes in geriatric patient, side effects of GERD related treatments, Influence of diet control and physical exercises in GERD and Diabetes, effects of dyslipidemia and obesity to GERD and type 2 diabetes, Effect of lifestyle modification to the patient and their treatment outcomes, Treatment options to geriatric GERD population along with diabetic medication uses. 


\section{Search Eligibility}

The systematic review was done from full text articles from 2015 to 2019 in English language. The articles include trials in humans. The geriatric population according to WHO guidelines was considered I.e. patients above 60 years old were added to the study. This systematic review tried to cover the global literature among various countries.

\section{Search keywords}

Different keywords were used in search I.e "geriatric with GERD”, "type 2 diabetes in geriatrics", "GERD related complications", "Pharmacotherapy of diabetes medications", "risk factors with diabetes medication", "treatment line for GERD I geriatrics"," complications related to GERD”.

\section{Primary search}

Different online data basis were used like pubmed, medline, Journals of American Geraitric society, The american journal of Gastroenterology, British journal of diabetes and vascular disease, Wiley Online Library, New England Journal of medicine, Caspian journal of internal medicine, British Medical Journal and clinical geriatric medicine were used in primary research.

\section{Secondary search}

Secondary search was gathered from the references available in the primary search. Primary screening was done to get the abstract. The articles which pass through the primary search are then used to gather inclusion criteria.

\section{Study selection and data extraction}

Many articles were reviewed to eliminate things irrelevant to our research criteria as shown in Figure 1. Patient's age was taken into consideration along with the metabolic syndrome.

\section{Quality Assessment}

Grace guidelines have 11 points in their checklist to determine the quality of the articles. It is used to evaluate quality of article and decision making. The 11 check points are categorized into data collection, records and the study population. ${ }^{[8]}$

\section{RESULTS AND DISCUSSION General Data}

The study data was collected from many countries like Japan, Nigeria, UAE and Malaysia. The study involve data of Geriatric population with GERD and type 2 diabetes mellitus hence the inclusion criteria is Geriatrics, type 2 diabetics and GERD patients. The study includes literature from 2015 onwards and hence no systematic review is included in it. The study focuses on literature done on clinical trials in humans. The total articles reviewed for this literature was 15 which were eligible to be added to this study as shown in Figure 2. It also shows the risk and therapy for Geriatric GERD patients

\section{Quality Assessment}

Not all the studies have included desired participants. Required information was recorded and stated objectively (risk factors and treatment plans) and few among them have shown missing data required to standardize measurements. ${ }^{\left[{ }^{[9}\right.}$ All the studies included have Geriatric type 2 diabetic patient and some includes type 2 diabetic obese patients. The further classification has been stated in Table 1 .

\section{Influence if diet control and physical exercises with GERD}

The data shows obese patients with BMI $>30 \mathrm{~kg} / \mathrm{m} 2$ with type 2 diabetes have higher chances of GERD. ${ }^{[10]}$ The findings also suggested increase in socioeconomic status shows increase incidence of type 2 diabetes mellitus with time and it also plays vital role to lifestyle modifications such as physical exercise and dietary habits. ${ }^{[0,11]}$ Therefore, the data suggested confounding variables like socio-demographic can be evaluated critically to avoid GERD among type 2 diabetes mellitus patients. ${ }^{[1]}$ The literature suggested lifestyle modification improve health benefits among the type 2 diabetes patients. Some literature suggested bariatric surgery for dual benefit of reducing the prevalence of GERD and Type 2 Diabetes Mellitus..$^{[9,11]}$

Similarly, literature suggested GERD related complication was decreased by maintaining lifestyle changes and weight reduction. ${ }^{[9]}$

\section{Effect of Lifestyle Modification to the Patient Treatment Outcome}

Diabetic patients who do not respond to medical treatments and lifestyle changes, surgery of bariatric has a very important role of our today's life..$^{[9,10]}$ Here, we hypothesis that weight loss after a sleeve gastrectomy can interrupt insulin resistance and prevent Type $2 \mathrm{DM}$ development. ${ }^{[1]}$ To maintain this hypothesis, we examined the effect of sleeve gastrectomy on $\mathrm{HbA}_{1 \mathrm{c}}$ in patients who don't have type 2 diabetes mellitus. ${ }^{[9]}$

The literature doesn't show the same thing but those with type 2 diabetes mellitus and those with collagen tissue disease, those with corticosteroids and those with age below $<18$ were excluded from the study. ${ }^{[11]}$ Age, gender, body mass index, the presence of additional illness, smoking, alcohol use, serum $\mathrm{HbA}_{1 \mathrm{c}}$ and cortisol levels were recorded before the operation. ${ }^{[9]}$ Body mass index (BMI) and cortisol levels were reevaluated at the first postoperative year. ${ }^{[0]}$

The literature doesn't have much similarities so patient with gastroparesis and type 1 vs type 2 diabetes and the role of sleeve gastroectomy on preventing type 2 diabetes mellitus result shows the percent and patient underwent cholecystectomy due to cholecysistis. ${ }^{[9,12]}$

\section{Influence of Eating Habit GERD}

In the population, Late night eating is associated with GERD. No evidence exists regarding the relationship between eating behaviors and GERD in patients with type 2 diabetes mellitus, though the prevalence of GERD in patients with type 2 diabetes is higher than in patients without diabetes. ${ }^{[10]}$ The study was conducted to investigate the association between eating behaviors and GERD in patients with type 2 diabetes. ${ }^{[1]}$

The prevalence values of GERD, skipping breakfast, snacking during bedtime, late night eating and eating fast were $32.0 \%, 13.7 \%, 27.1 \%, 28.8 \%$ and $44.4 \%$, respectively. ${ }^{[10]}$ Late night eating was independently positively associated with GERD in patients with type 2 diabetes; the adjusted odds ratio was 1.46 (95\% CI 1.03 to 2.05). No relationships were found between not eating breakfast, snacking at bedtime or eating fast and GERD. ${ }^{[1]}$ Eating late can positively be associated with GERD in patient with type 2 diabetes.

\section{Effect of Dyslipidemia and Obesity to GERD and Type $2 \mathrm{DM}$}

The occurrence of type $2 \mathrm{DM}$ with GERD is raising by sedentary lifestyle 
Table 1: Articles assessment and content identification.

\begin{tabular}{|c|c|c|c|c|}
\hline Authors & Design & Sample size & Drug & Conclusion \\
\hline 1. Hee L, et al. & Case-Control & $\begin{array}{l}\text { The research subjects included } \\
\text { patients with T2DM and a } \\
\text { healthy control group, all over } \\
40 \text { years of age, who received a } \\
\text { general checkup (including public } \\
\text { corporation checkup) during the } \\
\text { period between March } 2010 \\
\text { and December } 2010 \text { and who } \\
\text { provided informed consent for } \\
\text { data usage. }\end{array}$ & $\begin{array}{l}\text { The prevalence of GERD showed } \\
\text { no difference between the T2DM } \\
\text { patient group and the control group } \\
(32.6 \% \text { vs. } 35.9 \%, P=0.266) \text {. }\end{array}$ & $\begin{array}{l}\text { The prevalence of GERD in patients with T2DM } \\
\text { showed no difference from that of controls. GERD was } \\
\text { also not associated with peripheral and cardiovascular } \\
\text { autonomic neuropathy, age, or duration of DM in } \\
\text { patients with T2DM. }\end{array}$ \\
\hline 2. Luk, et al. & Retrospective study & $\begin{array}{l}\text { The Hong Kong HA, established } \\
\text { in } 1990 \text { and accountable to the } \\
\text { Hong Kong Special Administrative } \\
\text { Region Government, currently } \\
\text { manages } 42 \text { public hospitals } \\
\text { and institutions, } 47 \text { specialist } \\
\text { outpatient clinics and } 73 \text { general } \\
\text { outpatient clinics. }\end{array}$ & $\begin{array}{l}\text { Between the } 2000-2003 \text { and } \\
2010-2012 \text { periods, the proportion } \\
\text { of patients achieving } \mathrm{HbA} 1 \mathrm{c}<7.0 \% \\
\text { ( } 53 \mathrm{mmol} / \mathrm{mol} \text { ) was increased from } \\
32.9 \text { to } 50.0 \% \text {, blood pressure } \\
\leq 130 / 80 \mathrm{mmHg} \text {, from } 24.7 \text { to } 30.7 \% \\
\text { and } \mathrm{LDL} \text { cholesterol }<2.6 \mathrm{mmol} / \mathrm{L} \text {, } \\
\text { from } 25.8 \text { to } 38.1 \% \text {. }\end{array}$ & $\begin{array}{l}\text { Improvements in metabolic profile were identified, } \\
\text { in keeping with increases in the use of antidiabetic, } \\
\text { antihypertensive and lipid-lowering medications. }\end{array}$ \\
\hline 3. Korytkowski T, et al. & $\begin{array}{l}\text { Controlled Evaluation } \\
\text { (ADVANCE) } \\
\text { randomized trial. }\end{array}$ & $\begin{array}{l}\text { In the DPP, participants aged }>60 \\
\text { years (range } 60-85 \text { ) achieved } \\
\text { greater reductions in risk for } \\
\text { progression to type } 2 \text { diabetes } \\
\text { (T2D) with TLI compared with } \\
\text { younger age-groups or those } \\
\text { receiving metformin. }\end{array}$ & $\begin{array}{l}\text { In addition to insulin, there are } \\
\text { several different classes of oral } \\
\text { or noninsulin injectable glucose- } \\
\text { lowering therapies available for } \\
\text { achieving glycemic control } \\
\text { Metformin is no longer } \\
\text { contraindicated for individuals aged } \\
>80 \text { years or for those who have } \\
\text { mild chronic kidney disease (eGFR } \\
45-60 \mathrm{~mL} / \mathrm{min} \text { ). }\end{array}$ & $\begin{array}{l}\text { In summary, older adults with diabetes are at high risk } \\
\text { for ASCVD, warranting consideration of strategies that } \\
\text { reduce this risk. } \\
\text { Approximately } 50 \% \text { of adults aged } 64-75 \text { and }>75 \\
\text { years fall in the category of those with good to } \\
\text { intermediate health for whom targeted risk-factor } \\
\text { management is reasonable. }\end{array}$ \\
\hline Albanopoulos $\mathrm{K}$, et al. & Retrospective analysis & $\begin{array}{l}70 \text { patients with different co } \\
\text { morbidities such as } \\
\text { Type } 2 \text { diabetes } \\
\text { Dyslipidemia }\end{array}$ & $\begin{array}{l}\text { Treatment for T2D and dyslipidemia } \\
\text { was to regulate diet and engage } \\
\text { in physical exercise and also } \\
\text { significant reduction in weight }\end{array}$ & $\begin{array}{l}\text { Is effective and safe weight loss procedure for chinese } \\
\text { patients, the outcomes and resolution of comorbidities } \\
\text { at } 3 \text { years follow up. Further prospective studies } \\
\text { with larger sample size are needed to confirm our } \\
\text { conclusions }\end{array}$ \\
\hline 5. Suzuki Y, et al. & Prospective study & $\begin{array}{l}36 \text { report cases of GLP-1-RA- } \\
\text { related GERD like systems and } \\
\text { total sample used for this study } \\
\text { was } 654\end{array}$ & $\begin{array}{l}\text { GLP-1-RA } \\
\text { DPP-4 }\end{array}$ & $\begin{array}{l}\text { The administration of GLP-1-RA had a higher } \\
\text { incidence of GERD-like symptoms earlier than the } \\
\text { administration of DPP-4-Is. In this study, although } \\
\text { we think that further investigation is necessary and } \\
\text { suggest that patients older than } 70 \text { years of age who } \\
\text { have been administered GLP-1-RAs need earlier } \\
\text { attention to address GERD-like symptoms than } \\
\text { younger patients. }\end{array}$ \\
\hline $\begin{array}{l}\text { 6. Miras AD, Kamocka } \\
\mathrm{A} \text {, et al. }\end{array}$ & Retrospective analysis & $\begin{array}{l}\text { Total was } 50,782 \text { which includes: } \\
\text { T2D } \\
\text { HTN } \\
\text { DYSLIPIDEMIA } \\
\text { GERD } \\
\text { OBESITY }\end{array}$ & $\begin{array}{l}\text { Obesity surgery was particularly } \\
\text { effective on functional impairment } \\
\text { and diabetes, patients with diabetes } \\
\text { related hyperglycemia compared } \\
\text { with preoperatively. surgery was } \\
\text { safe with a morbidity of } 3.1 \% \text { and in } \\
\text { hospital mortality of } 0.7 \% \text { and } \\
\text { reduced median inpatient stay of } 2 \\
\text { days, despite an increasingly sick } \\
\text { patient population. }\end{array}$ & $\begin{array}{l}\text { Obesity surgery in the U.K. results not only in } \\
\text { weight loss, but also in substantial improvements in } \\
\text { obesity-related co-morbidities. Appropriate support } \\
\text { and funding will help improve the quality of the NBSR } \\
\text { data set even further, thus enabling its use to inform } \\
\text { healthcare policy. }\end{array}$ \\
\hline 7. Fujiwara, et al. & Retrospective & $\begin{array}{l}\text { The study included } 57 \text { patients } \\
\text { with type } 2 \text { diabetes mellitus }\end{array}$ & $\begin{array}{l}\text { Life style modification } \\
\text { Oral Agent } \\
\text {.Insulin }\end{array}$ & $\begin{array}{l}\text { Infections such as } H \text {. Pylori And GERD not appear in } \\
\text { type } 2 \text { Diabetic mellitus patient }\end{array}$ \\
\hline 8. Chin, et al. & Retrospective & N/A & Lifestyle and dietary measure & $\begin{array}{l}\text { Incidence of gastroesophageal reflux disease (GERD) } \\
\text { showed an increasing trend resulting from factors, } \\
\text { including lifestyle and dietary habits. And Increasing } \\
\text { evidence suggests GERD has specific connections } \\
\text { with a variety of non-digestive tract conditions, may } \\
\text { contribute an aggravating compounding effect on } \\
\text { other diseases, prolong hospitalization and increase } \\
\text { subsequent medical costs }\end{array}$ \\
\hline 9. Takeshita E, et al. & $\begin{array}{l}\text { Self administered } \\
\text { questionnaire }\end{array}$ & $\begin{array}{l}817 \text { Japanese patients with type } 2 \\
\text { diabetes mellitus }\end{array}$ & No treatment has used & $\begin{array}{l}\text { Late night dinner may be positively associated with } \\
\text { GERD in Japanese patients with type } 2 \text { diabetes } \\
\text { mellitus }\end{array}$ \\
\hline 10. Yoshio I, et al. & $\begin{array}{l}\text { Multicenter cross } \\
\text { sectional study }\end{array}$ & $\begin{array}{l}847 \text { Japanese patients with type } 2 \\
\text { diabetes mellitus }\end{array}$ & $\begin{array}{l}\mathrm{PPI} \text { or Histamine } \mathrm{H} 2 \text { receptor } \\
\text { antagonist }\end{array}$ & $\begin{array}{l}\text { Younger age may be independently positively } \\
\text { associated with GERD in Japanese patients with type } \\
2 \text { diabetes mellitus regardless of the use of PPI or } \\
\text { H2RA }\end{array}$ \\
\hline 11. Drahos et al. & Case control study & N/A & No treatment has used & $\begin{array}{l}\text { The systemic inflammatory state (MetS) may } \\
\text { represent a reflux-independent inflammatory pathway } \\
\text { that increases the risk of BE. MetS did not increase } \\
\text { risk of EA in this study population. }\end{array}$ \\
\hline
\end{tabular}




\begin{tabular}{|c|c|c|c|c|}
\hline $\begin{array}{l}\text { 12. Hafez D, Fedewa } \\
\text { A, et al. }\end{array}$ & $\begin{array}{l}\text { retrospective } \\
\text { analysis }\end{array}$ & $\begin{array}{l}29 \text { patients with different co } \\
\text { morbidity such as } \\
\text { hypertension } \\
\text { gastroesophageal }\end{array}$ & lifestyle changes & $\begin{array}{l}\text { This present study we found that bariatric surgery } \\
\text { caused a significant decrease in HbA1c levels in non- } \\
\text { diabetic patients, suggesting that bariatric surgery may } \\
\text { prevent Type } 2 \text { Diabetes Mellitus in obese patients. }\end{array}$ \\
\hline 13. Oluyemi A, et al. & A case-control design & $\begin{array}{l}100 \text { patients with } \\
\text { diabetes mellitus } \\
\text { gastroesophageal reflux }\end{array}$ & Lifestyle modification & $\begin{array}{l}\text { Infection with } \mathrm{H} \text {. pylori does not appear, from the } \\
\text { results of this study, to influence the prevalence and } \\
\text { patterns of upper Gl symptoms in patients with DM. }\end{array}$ \\
\hline $\begin{array}{l}\text { 14. Abell TL, Bernstein } \\
\text { VK, et al. }\end{array}$ & Questionnaire & $\begin{array}{l}78 \text { patients with TIDM and } 59 \\
\text { patients with T2DM }\end{array}$ & Metformin & $\begin{array}{l}\text { Baseline symptoms were similar in T1DM and T2DM } \\
\text { patients, even though T1DM patients had worse } \\
\text { gastric emptying delays and higher HbA1c }\end{array}$ \\
\hline
\end{tabular}
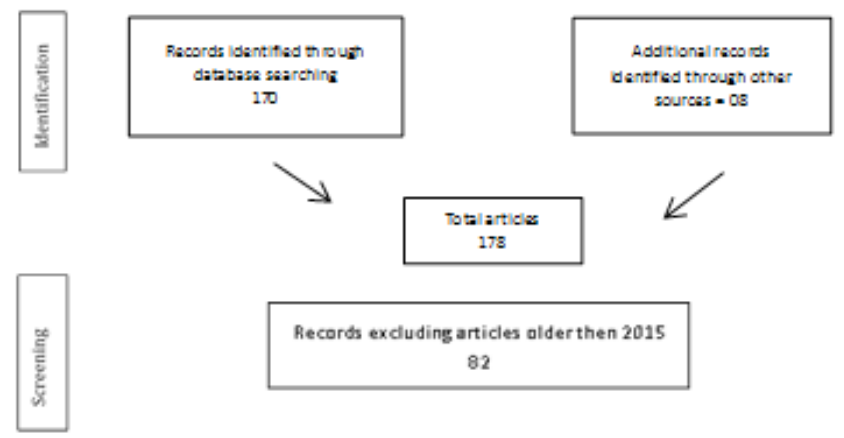

82

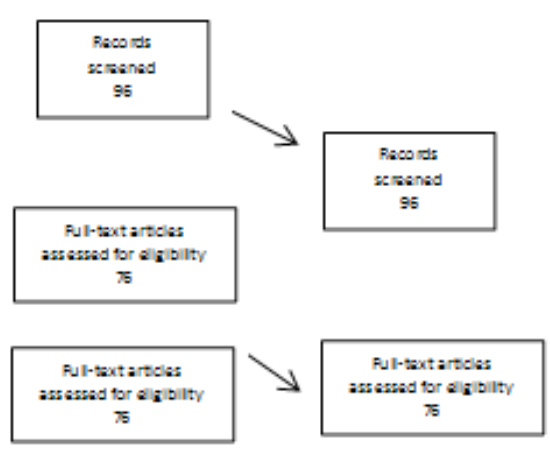

Figure 1: Prisma Diagram of systematic review.

or a problem of disease such as dyslipidemia. ${ }^{[9]}$ In scientific literature show the usage of gastrostomy in patient accompanied with diabetes mellitus and their progress in post-surgery. ${ }^{[12]}$

After gastrostomy that patients with type 2 diabetes mellitus improve outcome. However, it has proven that $48 \%$ percent haven't reported any signs within the $1^{\text {st }}$ year. ${ }^{[12]}$ Moreover, a noticeable reduction from $30 \%$ of type $2 \mathrm{DM}$ to $10 \%$ over 5 years of time was reported; likewise, $25 \%$ of patients with dyslipidemia reduced to $5 \%$ over 5 years as soon in Figure $3{ }^{[12]}$ Literature showed similarity regarding factors such as DM with dyslipidemia and obesity, hence the results suggested type 2 patient improve after surgery. ${ }^{[13]}$

\section{GERD with GLP-1-RAs}

GLP-1- RAs are more effective than conventional sulfonylurea drugs and glinide drugs for treating type 2 diabetes, in which hypoglycemia and increased body weight are less likely to occur and in which insulin secretion is reduced. Obesity surgery was particularly effective in functional impairment and diabetes. ${ }^{[11]}$

Obesity surgery and gastro reflux disease may not relate to each other. In one of the literatures it shows that obesity surgery was mostly active on functional impairment and diabetes and reducing the percentage of patients with diabetes-related hyperglycemia. ${ }^{[0]}$ Surgery was done safely with morbidity of $3.1 \%$ and in-hospital death of $.07 \%$ and a condensed average inpatient

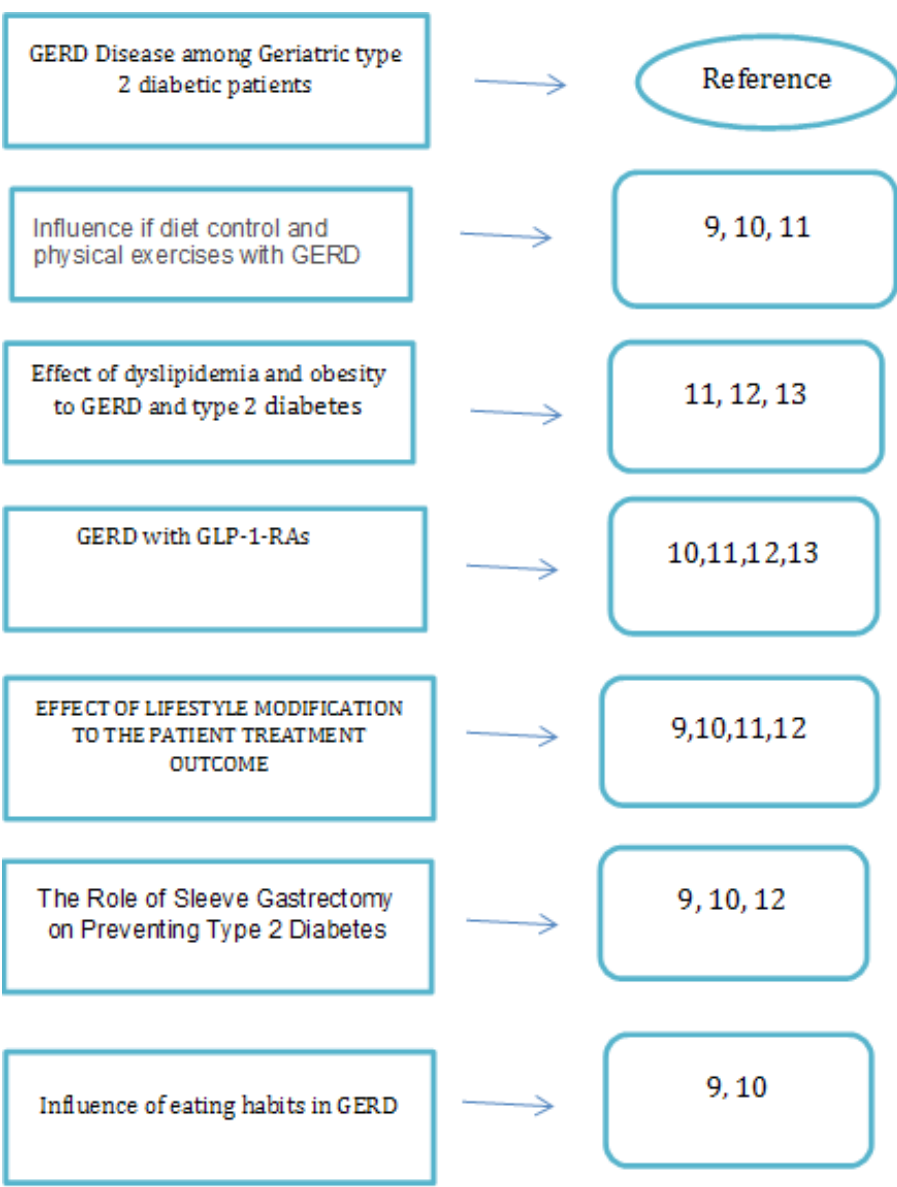

Figure 2: Systematic Review blueprint.

stay of 2 days, even though a spike increases in sick patient population. ${ }^{[12]}$ Between the incretin-based drugs, there were 2 GLP-1-RAs for which signs of Gerd-like symptoms were noticed. In assessment, all DPP-4-Is were not perceived. ${ }^{[12]}$

Both literatures may contraindicate and we should have a better understanding of gastro reflux diseases and obesity surgery if further research or RCT's has been performed on this subject. ${ }^{[12,13]}$ Single blind trials are recommended to evaluate the effect of GLP-1-Ras receptor agonist among patients with GERD 2 disease and type 2 diabetic. ${ }^{[13]}$

\section{The Role of Sleeve Gastrectomy on Preventing Type 2 Diabetes}

This literature is proving that DM type 2 is a preventable disease in which we can provide insulin doses to the patients as a treatment. For obese patients bariatric surgery is preferred instead of insulin treatment. Never less this 
literature is proving that the effect of sleeve gastrostomy on $\mathrm{HbA}_{1 \mathrm{c}}$ in patients without type 2 diabetes mellitus. ${ }^{[10]}$

One of the risk factors regarding bariatric surgery is that it reduces over time after surgery and it may lead to serious conditions. ${ }^{[10]}$ Nerveless there should be a precaution while using preventive medicine regarding the bariatric surgery. According to literature, bariatric surgery leads to a slight increase of cortisol level in patients and weight loss as soon in Figure 4. ${ }^{[11]}$ Depending on the metabolic and endocrinological effects of obesity, type 2 diabetes mellitus [DM], dyslipidemia, hypertension, cardiovascular diseases, gastroesophageal reflux disease, degenerative joint disease, cholelithiasis, hepatosteatosis and some types of cancer may develop. ${ }^{[12]}$ Further investigations are required about the disadvantages for this surgery. ${ }^{[12]}$

\section{Common risk and measures for Geriatrics}

As the age increase, the risk of health deterioration increases as well, so to maintain health and avoid crises of health some essential measures have to be taken for special population like geriatrics. High sugar intake and process food usage is increases diabetes whereas no exercise habits among some geriatrics are increasing the risk by any folds. Polypharmacy is the most debatable thing in chronic illness patients where it can cause Gastro-intestinal symptoms. After that depression is also affecting the patient life by implying extra stress on patients, hence worsening their symptoms. Some of the health crises and measures to avoid them are mentioned in Figure 5. ${ }^{[14]}$

Type 2 Diabetes Mellitus risks and measures to be taken in Geriatric population.

\section{Sleeve gastrectomy \& Obesity surgery}

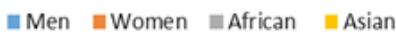

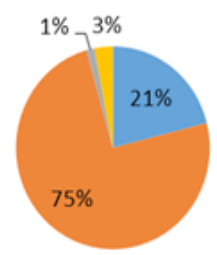

Figure 3: Ratio of sleeve gastrectomy and obesity surgery among different sex and race.

\section{Obesity Surgery Mortality Risk Score $=3.6 \%$}

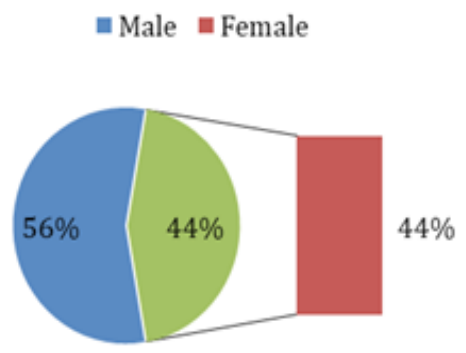

Figure 4: Obesity Surgery mortality risk score among male and females.
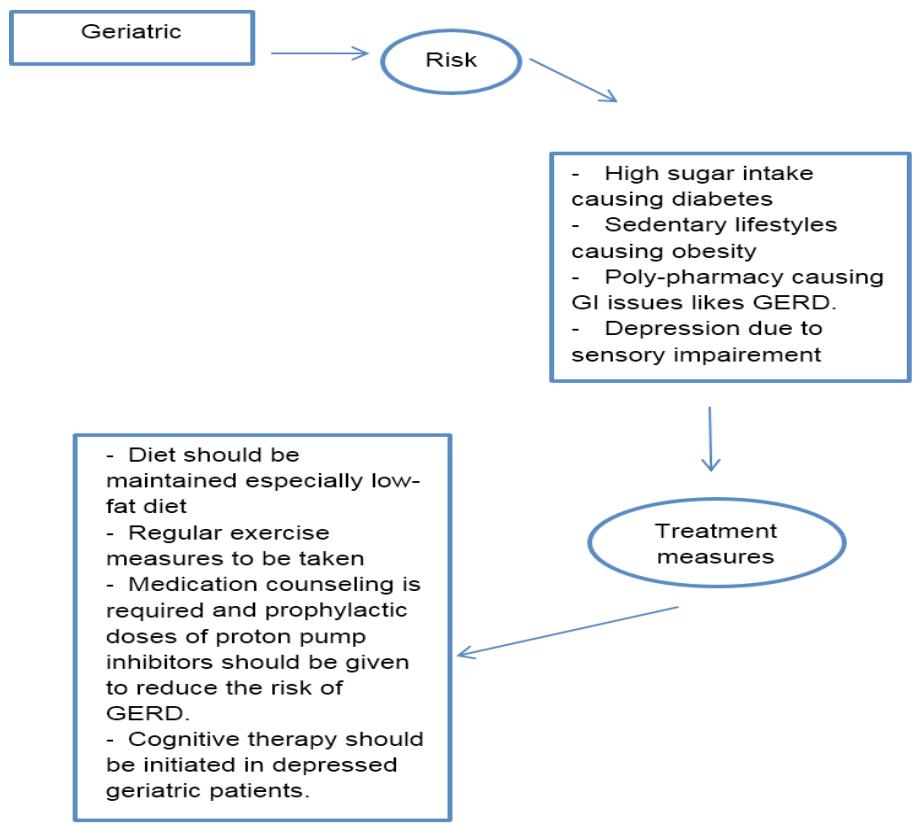

Figure 5: Common risks and treatment measures in Geriatric patients.

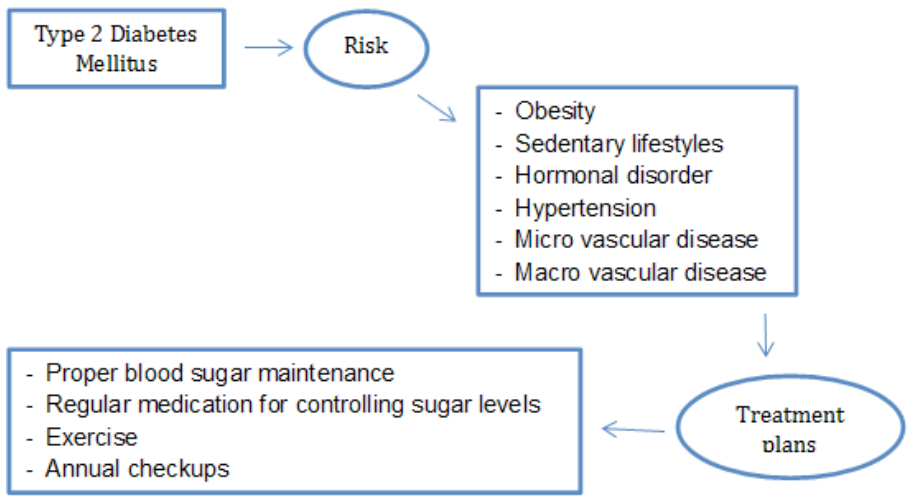

Figure 6: Risk factors and treatment measures in type 2 diabetic patient.

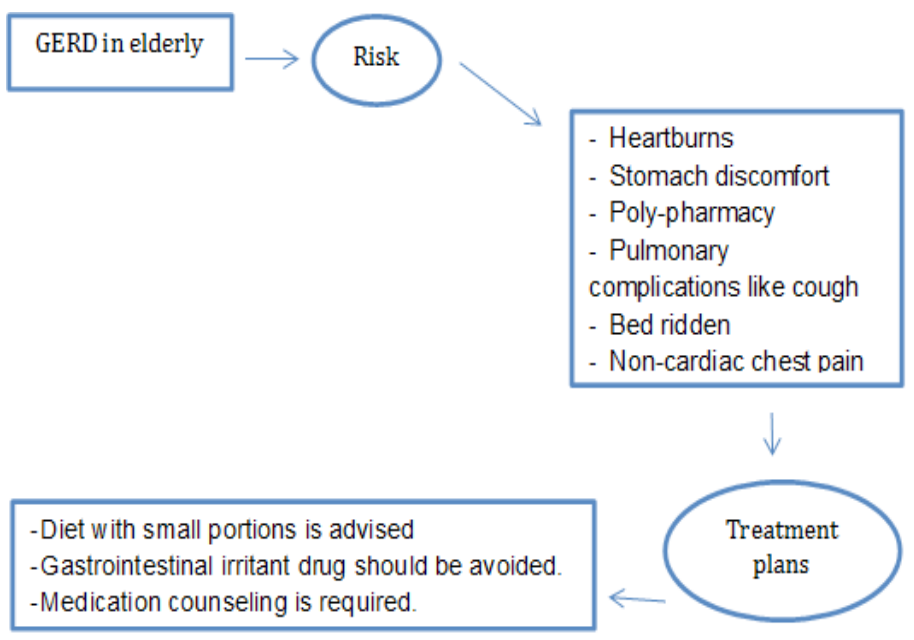

Figure 7: Risk factors and treatment measures in Gastroesophageal reflux disorder in Geriatric patients. 
Diabetes has been one of common condition in old age and hence decreases the life span by causing metabolic disturbances. In elderly patients, diabetes medication can cause gastrointestinal disturbances as GERD and hence medication counseling should be properly done. The patient should be assessed for micro and macro vascular diseases as they are at higher risk. One the most concerning thing in elderly is Hormonal dysfunction as well which is making the ongoing conditions in even worse. The Figure 6 describes the risk and measures more concisely. ${ }^{[15]}$

\section{GERD in Geriatric patients}

Elderly population is at higher risk of GERD related complications like pneumonia, bronchitis, cough etc. The acidity increases with age and hence metabolic disorders and sedentary lifestyle increase the risk too. ${ }^{[15]}$ The bedridden elderly patients are among high risk patients for the GERD related complications. ${ }^{[15]}$ The extrapulmonary complications are increasing the mortality rate in elderly. ${ }^{[15]}$ In order, to minimize the risk some special measures have to be taken as shown in Figure 7.

\section{CONCLUSION}

GERD and its related complication are very common in Geriatric patients. The elderly population was special because they showed very little symptoms and very severe damage. The patients with type 2 diabetes are at double risk of GERD as this metabolic disorder was making it worst. GERD can be avoided by minimizing the risk of type 2 diabetes either by controlling obesity by bariatric surgery or by exercise and more active lifestyle. Diabetes medication should also be monitored as some of them like Glucagon-likepeptide-1 receptor agonists can cause GERD. There are some important considerations to decrease the incidence of GERD by evaluation and treatment in the older patients. Moreover with good management, GERD and its complications can be treated easily in elderly patients.

\section{Limitations of the Review}

The studies on special populations like geriatrics are very rare and thus collection of data was hard. The elderly patients are not taken under consideration of many trials. The GERD related type 2 diabetes in geriatric is less, the management of type 2 diabetes has limited knowledge, hence RCTs and meta-analysis specific to geriatric population is required to understand and optimize treatment management to population specific needs.

\section{ACKNOWLEDGEMENT}

None.

\section{CONFLICT OF INTEREST}

The authors declare no conflict of interest.

\section{ABBREVIATIONS}

GERD: Gastroesophageal reflux disorder; T2DM: Type 2 diabetes mellitus;
GLP1-RA: Glucagon-like peptide-1 receptor agonist; DPP-4: Dipeptidyl peptidase 4; PPIs: Proton-Pump Inhibitors; HTN: Hypertension; eGFR: Estimated glomerular filtration rate; $\mathbf{H b A}_{1 \mathbf{c}}$ : Glycated hemoglobin A1c.

\section{REFERENCES}

1. May D, Thiman M, Rao SC. Gastroesophageal Reflux Disease. In: eds. Pharmacotherapy: A Pathophysiologic Approach, 11e New York, NY: McGrawHill. 2019.

2. Mertz $\mathrm{H}$. Functional disorders of the gastrointestinal tract. Philadelphia $(\mathrm{Pa}$.$) :$ W.B. Saunders. 2003.

3. Hafez D, Fedewa A, Moran M, O'Brien M, Ackermann R, Kullgren JT. Workplace Interventions to Prevent Type 2 Diabetes Mellitus: A Narrative Review. Curr Diab Rep. 2017;17(2):9. https://doi.org/10.1007/s11892-017-0840-0 .

4. Quan C, Talley NJ, Cross S, Jones M, Hammer J, Giles N, et al. Development and validation of the diabetes bowel symptom questionnaire. Aliment Pharmacol Ther. 2003;17(9):1179-87.

5. Jung HK, Choung RS, Locke GR, Schleck CD, Zinsmeister AR, Szarka LA, et al. The incidence, prevalence and outcomes of patients with gastroparesis in Olmstead County, Minnesota, from 1996 to 2006. Gastroenterology. 2009;136(4):1225-33.

6. Özdaş S, Olt S, Şirik M. The Role of Sleeve Gastrectomy on Preventing Type 2 Diabetes Mellitus. Open Access Maced J Med Sci. 2017;5(3):316-8. Published 2017 Jun 11. doi:10.3889/oamjms.2017.07

7. Salehi M, VahI TP, D'Alessio DA. Regulation of islet hormone release and gastric emptying by endogenous glucagon-like peptide 1 after glucose ingestion. J Clin Endocrinol Metab. 2008;93(12):4909-16. doi: 10.1210/jc.2008-0605.

8. Dreyer NA, BryantA, Velentgas P. The GRACE Checklist: A Validated Assessment Tool for High Quality Observational Studies of Comparative Effectiveness. Journal of Managed Care and Specialty Pharmacy. 2016;22(10):1107-13.

9. Takeshita E, Furukawa S, Sakai T, Niiya T, Miyaoka H, Miyake T, et al. Eating Behaviours and Prevalence of Gastroesophageal Reflux Disease in Japanese Adult Patients with Type 2 Diabetes Mellitus: The Dogo Study. Canadian Journal of Diabetes. 2018;42(3):308-12.

10. Chen Y. Gastroesophageal reflux disease and non-digestive tract diseases. Expert Review of Gastroenterology and Hepatology. 2015;9(5):685-92.

11. Koch KL, Hasler WL, Yates KP, et al. Baseline features and differences in 48 week clinical outcomes in patients with gastroparesis and type 1 vs type 2 diabetes. Neurogastroenterol Motil. 2016;28(7):1001-15. doi:10.1111/nmo.12800

12. Miras AD, Kamocka A, Patel D, et al. Obesity surgery makes patients healthier and more functional: Real world results from the United Kingdom National Bariatric Surgery Registry. Surg Obes Relat Dis. 2018;14(7):1033-40. doi:10.1016/j. soard.2018.02.012

13. Wang X, Chang X, Gao L, Zheng C, Zhao X, Yin K, et al. Effectiveness of laparoscopic sleeve gastrectomy for weight loss and obesity-associated comorbidities: A 3-year outcome from Mainland Chinese patients. Surgery for Obesity and Related Diseases. 2016;12(7):1305-11.

14. Noguchi $\mathrm{Y}$, Katsuno $\mathrm{H}$, Ueno A, Otsubo $\mathrm{M}$, Yoshida A, Kanematsu $\mathrm{Y}$, et al. Signals of gastroesophageal reflux disease caused by incretin-based drugs: A disproportionality analysis using the Japanese adverse drug event report database. Journal of Pharmaceutical Health Care and Sciences. 2018;4(1):15.

15. Chait MM. Gastroesophageal reflux disease: Important considerations for the older patients. World J Gastrointest Endosc. 2010;2(12):388-96. doi:10.4253/ wjge.v2.i12.388 